\title{
Subverting the Ivory Tower: Teaching and \\ Learning Through Critical Dialogues
}

\section{Elizabeth J. Meyer and Veronika Lesiuk}

\section{Introduction}

Joe Kincheloe was our teacher, our mentor, and our friend. In our experiences in higher education, we had learned that it was virtually impossible to have these three different kinds of relationships with one person; particularly with an established, respected scholar who was as prolific as he was. He wasn't arrogant or inaccessible or a diva or blinded by the hubris that can come with being deemed an "expert in the field." He was Joe, the Vols fan and blues musician from Tennessee who proudly told anyone who would listen about his honorary membership in the Lesbian Avengers. When we first met him, he was also Dr. Joe L.

Kincheloe, the Canada Research Chair in critical pedagogy at McGill University and renowned scholar and author or editor of more than 40 books. However, the mere presence of Joe and his work in cultural studies, social theory, and critical pedagogy existing in the Ivory Towers of top-tier research universities was an act of subversion. He preferred T-shirts and jeans to jackets and ties. He befriended the custodial staff before getting to know the department chairs, and he never made it to a meeting on time because he was busy listening to someone. Even more than his presence, his teaching subverted the expectations and the unwritten rules of these elite institutions.

\section{Classroom Conversations}

We were quite confused and destabilized during our first few weeks of class with Joe. We kept waiting for him to outline his objectives for the semester, to explain the course projects and tell us 
how we would be graded. We kept waiting for a formal lecture that we could take notes on so we could master the material and work to meet the professor's expectations. Needless to say, as a critical pedagogue, and the first of his kind we had ever encountered during our many years of postsecondary education, Joe did none of these things. Some grew frustrated and felt lost by the lack of structure, the long conversations, and the lack of "respect" for the classroom setting. Others found it refreshing. He might answer a phone call in class, or his partner, Shirley Steinberg, could wander in from time to time with their hypoallergenic dog, Ozzy, for a quick chat, or the Dean would drop in just to listen in on the classroom conversations. As students who had usually done well in school, who had carefully learned the rules of classrooms, and even reinforced them as teachers, we were destabilized, frustrated, and confused by these activities. As the semester wore on, we realized we were being pushed to think harder than we had in any other course, doing additional readings out of our own interests and listening more carefully to our peers than ever before. Joe was slowly, intentionally, and successfully tearing down and reshaping the classroom boundaries subverting the Ivory Tower-and opening up new spaces for dialogue, learning, and unlearning. For example, a group of us that first met in his class, collaborated on a book project that built on these relationships and the trust established in that class and wrote about our personal and emotional journeys that supported our intellectual understandings of critical discourses (Churchill, 2009).

Joe was the first professor that we had comfortably addressed by his first name while in his class. His voice, his demeanor, his pedagogy, all cultivated an atmosphere of trust, openness, and respect for each student's identities and experiences. He shared the approach to teaching articulated by bell hooks. She wrote, “the professor must genuinely value everyone's perspective. There must be an ongoing recognition that everyone influences the classroom dynamic, that 
everyone contributes" (hooks, 1994, p. 8). That year, in both Joe and Shirley's classes, we were amazed at how much we learned about and from our fellow classmates. In no previous course had students opened up as much about their own selves, their own identities, and their own miseducative experiences (Dewey, 1938/1963) as they did in Joe and Shirley's classes. We had struggled for years to find or create a student community during our graduate studies, and it was no coincidence that several such communities finally emerged the year that Joe and Shirley arrived. Joe's warmth, generosity, and unconditional support helped draw people in. He made it clear that he cared for us not just as students but as a whole people. He wrote about this love that is central to his notion of critical pedagogy and stated,

If critical pedagogy is not injected with a healthy dose of what Freire called "radical love," then it will operate only as a shadow of what it could be. Such a love is compassionate, erotic, creative, sensual, and informed. Critical pedagogy uses it to increase our capacity to love, to bring the power of love to our everyday lives and social institutions and to rethink reason in a humane and interconnected manner. Knowledge in this context takes on a form quite different from its more accepted and mainstream versions. A critical knowledge seeks to connect with the corporeal and the emotional in a way that understands at multiple levels and seeks to assuage human suffering. (Kincheloe, 2005, p. 3)

This love extended beyond the walls of the classroom as he and Shirley invited students home and into their lives. They welcomed both of us into their world through what we have come to call the "Pedagogy of the Party." 


\section{The Pedagogy of the Party}

Joe and Shirley would invite students over to their house a few times during the school year. Current, former, and future students would gather with their partners, children, and friends in the colorful and music-filled spaces of their home. These gatherings fostered the development of strong personal and intellectual relationships and expanded the spaces of learning and inquiry far beyond the walls of the Ivory Tower. The "Pedagogy of the Party" is meant to highlight how these ostensibly social gatherings allowed us all to extend our relationships and understandings of each other and what we were learning beyond an isolated, disembodied, intellectualized group of students who were enrolled in a graduate course that met once a week. As Giroux explains, "meaning is located in the various dimensions of subjectivity and behavior as well as in 'texts' and classroom practices that structure, limit, and enable human action" (Giroux, 1983, p. 157). These parties allowed the learning and the radical love that started in Joe's classes to pour over into our personal lives so we could be our whole selves and draw on our identities, our experiences, and our situated histories as legitimate ways of knowing. Many professors and teachers work to bracket their subjectivities and build high walls between their personal and professional lives. This differentiation of public/private selves is difficult to navigate as it is often impossible to leave behind key aspects of our identities or past experiences when we interact with others in educational settings without feeling fractured or hypocritical (Maher \& Tetreault, 1994; Meyer, 2008). Joe modeled how a teacher and a mentor can effectively remove these barriers to learning and become a trusted friend by listening to other's stories and validating each of these experiences as educative, important, and full of meaning. Joe helped each of us be more fully present in our learning because he saw us, knew us, and valued us for our intellectual contributions and our whole selves. 
Through the Pedagogy of the Party, Joe helped create an atmosphere of what we had hoped graduate school would be like but had never experienced before we met him. He fostered a community of learners who engaged in critical dialogues that radically transformed the way we learn and conceptualize "teaching" and will continue to do so. He made us each feel valued because he chose to take the time to listen. He would then share a story from his own life that was filled with insights and connections that made us laugh and feel truly heard. He was a noncompetitive, humble, Socratic professor who also offered the best model of Paulo Freire's Pedagogy of the Oppressed that we have ever experienced. Teaching through conversations and constructing the Pedagogy of the Party allowed learning to happen in important ways. As Freire explained, "I engage in dialogue because I recognize the social and not merely the individualistic character of the process of knowing. In this sense, dialogue presents itself as an indispensable component of the process of both learning and knowing" (Freire \& Macedo, 1995, p. 379). These dialogues that were sparked by Joe's presence, love, and teaching were indispensable in our own processes of learning and knowing.

\section{Conclusion}

Joe would often tell the story of the night he first encountered Paulo's work in the library of the small Christian college he attended and how he was so drawn in that he stayed up all night reading The Pedagogy of the Oppressed. Freire's ideas so deeply resonated with what Joe already felt and knew to be true and offered support and external legitimacy to his own developing concepts of liberation theology and social justice. As Donaldo Macedo points out in the introduction to the 30th Anniversary edition of Pedagogy of the Oppressed, "people often identify with 
representations that they are either comfortable with or that help deepen their understanding of themselves" (Macedo, 2007, p. 23).

Joe Kincheloe embodied all the qualities Freire believed were elements for engaging in meaningful dialogues: love, humility, faith in humankind, mutual trust, hope, and critical thinking (Freire, 1970/1993, pp. 88-92). Although some may argue that these were part of his inherent nature even before encountering the work of Paulo Freire, it is important to acknowledge that all educators can learn to infuse our work and our relationships with love, humility, faith in others, trust, hope, and criticality. These qualities that Joe showed helped us shift our learning from our heads to our hearts and shifted his relationship with us from teacher, to mentor, to beloved friend in our lives. He is a dear and cherished role model who has provided us with a lifetime of strength and inspiration to continue subverting the Ivory Tower and pursuing critical dialogues in all the learning spaces that have opened up around us.

\section{References}

Churchill, A. H. (Ed.). (2009). Rocking your world: Emotional journeys in the critical discourses. Rotterdam, Netherlands: Sense Publishers.

Dewey, J. (1963). Experience and education. New York: Collier Books. (Original work published 1938)

Freire, P., \& Macedo, D. (1995). A dialogue: Culture, language, and race. Harvard Educational Review, 65, 375-389.

Freire, P. (1993). Pedagogy of the oppressed (M. B. Ramos, Trans.).

New York: Continuum. (Original work published 1970) Giroux, H. (1983). Theory and resistance in education. South

Hadley, MA: Bergin \& Harvey.

hooks, b. (1994). Teaching to transgress: Education as the practice of freedom. New York: Routledge-Falmer.

Kincheloe, J. (2005). Critical pedagogy. New York: Peter Lang. Macedo, D. (2007). Introduction. In The pedagogy of the oppressed (30th Anniversary ed., pp. 11-27). New York: Continuum.

Maher, F. A., \& Tetreault, M. K. T. (1994). The Feminist Classroom. New York: Basic Books. Meyer, E. (2008). Who we are matters: Exploring teacher identities through found poetry. LEARNing Landscapes, 1, 195-210. 


\section{Bios}

Elizabeth J. Meyer is an assistant professor of education at Concordia University in Montreal, Quebec, Canada. She was a high school teacher for 5 years in the United States and France and completed her PhD at McGill University, Montreal. She is the author of two books: Gender, Bullying, and Harassment: Strategies to End Sexism and Homophobia in Schools and Gender and Sexual Diversity in Schools: An Introduction. Her work has also been published in Gender and Education, Computers and Education, the McGill Journal of Education, and the Journal of LGBT Youth.

Veronika Lesiuk completed her BSc in athletic therapy at Concordia University and her MSc in Kinesiology at McGill University. Her master's thesis was on the subject of heart rate variability and respiratory sinus arrhythmia. Part of this res earch was published in Autonomic Neuroscience. She worked for 10 years in e-learning both at Concordia University and eConcordia. 